\title{
The local employment impacts of mining: an econometric analysis of job multipliers in northern Sweden
}

\author{
Thomas Moritz $^{1} \cdot$ Thomas Ejdemo $^{1} \cdot$ Patrik Söderholm $^{1} \cdot$ Linda Wårell $^{1}$
}

Received: 18 November 2016 / Accepted: 23 January 2017 /Published online: 6 February 2017

(C) The Author(s) 2017. This article is published with open access at Springerlink.com

\begin{abstract}
The way in which mining contributes to job opportunities in the region where it takes place has become increasingly important for the industry's relations to the local community. The employment impacts of mining are however far from straightforward to assess. Considering these uncertainties about real-life job impacts, it is vital that there are sound assessments of these employment effects. The purpose of this paper is to apply a novel econometric approach to assess mining-induced job multipliers in the empirical context of northern Sweden. This analysis employs data on the number of employees in selected non-mining sectors and in the mining sector, respectively, and covering the relatively recent mining boom period (2003-2013). We also highlight differences across the two main mining counties in northern Sweden. The results show a positive statistical relationship between increases in the number of employees in the mining sector and changes in the number of employees in other sectors. The private services' sector is particularly affected, while the industrial sector also benefits in the specific case of mining municipalities. The results also indicate relatively large intercounty differences, in turn highlighting the importance of addressing the context-specific circumstances when estimating the employment effects of mining.
\end{abstract}

Keywords Mining employment · Job multiplier .

Econometric analysis $\cdot$ Sweden

Linda Wårell

linda.warell@1tu.se

1 Economics Unit, Luleå University of Technology, SE-971 87 Luleå, Sweden

\section{Introduction}

This paper addresses the challenges involved in assessing the local employment impacts of mining activity. It employs a novel econometric approach based on reported employment data in the empirical context of Swedish municipalities. This permits an assessment of so-called job multipliers and a comparison of such multipliers based on other employment impact assessment methods.

Since the beginning of the new century, the global mining industry has experienced high volatility, in particular represented by a period of soaring output prices and subsequently a bust. During the boom period-from 2004 to 2014 - there was a strong increase in mining investments, including the opening of a large number of new mines around the world. In most developed countries, mining takes place in remote regions with declining population trends, and this has led to a demand for a more inclusive mining sector. Host communities in countries with substantial mining investment (e.g., Australia, Canada, the Nordic countries, etc.) have increasingly emphasized the need for a more even sharing of the benefits of mining activity (e.g., O'Faircheallaigh 2013). Regional growth and local employment opportunities are often essential components of such expectations (e.g., Williams 2012; Prno 2013). Thus, the way in which mining contributes to job opportunities in the region where it takes place has become increasingly important for the industry's relation to the local community.

The employment impacts of mining are however far from straightforward to assess, not the least since falling transport costs and technological progress have led to projects that sometimes are increasingly economically detached from the regions in which they are located (e.g., Eggert 2001). The industry has over time become more capital-intensive, thus leading to a decrease in the demand for local labor. 
Moreover, the inputs into new mining projects must generally satisfy high technological standards, which often cannot be supplied competitively by local firms. This was pointed out already by Radetzki (1982). For these reasons, there have also been strong concerns over so-called fly-in fly-out work practices, i.e., where long distance commuting replaces inmigration (World Bank 2010). Indeed, the local employment effects that stem from the investment phase can sometimes be modest in the case of small host municipalities compared to those arising during the operating phase. Big firms tend to get the main contracts, and it is not always easy for local firms to act as sub-contractors, etc. These possibilities may improve during the operating phase as maintenance and repair firms set up subsidiaries in the host municipality.

This suggests that the employment impacts of mining activities tend to be highly region-specific. For instance, the larger the region is, the more likely that it will have the capacity and the labor skills to capture the expenditures. The extent to which the inputs for the mining activities will be purchased in the region will also be determined by the existing industrial structure, where more diversified regional economies will be better equipped to meet the new demands for goods and services (Rolfe et al. 2007). Considering these uncertainties about real-life job impacts, it is vital that there are sound assessments of the employment effects from mining. If mining cannot be seen as a vehicle for regional development and job creation, community relations may become tense and lead to costly conflicts as well as to other types of business risks for the companies (Söderholm and Svahn 2015).

A common method in regional impact analyses is to employ so-called input-output $(\mathrm{I} / \mathrm{O})$ modeling, pioneered by Leontief (1936) and developed for regional analysis by Isard (1951), which formalizes the linkages between various sectors in an economy. This methodological approach has typically been applied ex ante, ${ }^{1}$ and can be used to assess the employment impacts from an exogenous change to the regional economy, such as a major mining investment. One output from I/O models is the so-called job multiplier, which states how many new jobs that are created in the rest of the regional economy when one new job in the mining industry is created. However, the use of $\mathrm{I} / \mathrm{O}$ modeling has been criticized for building on restrictive assumptions, such as the absence of any agglomeration effects as well as factor supplies not responding to price changes (Fleming and Measham 2014; Eggert 2001). This last assumption may be particularly restrictive, as it by default implies a positive job multiplier (Weber 2012). ${ }^{2}$ Since a considerable part of the economic value of mining today is tied up with the manner of how mining operations are performed

\footnotetext{
${ }^{1}$ In principle, one could use I/O models to make also ex post assessments, but as noted below, this approach could impose too many restrictions (e.g., inelastic factor supplies, zero transaction costs, etc.).

${ }^{2}$ This also implies that I/O modeling might be relevant for short-run assessments, i.e., for addressing the impacts before relative prices have changed.
}

rather than with the initial investment itself, greater attention should be devoted to how regional economies can supply the necessary competence to support modern mining ventures. For the above reasons, there has been an increased interest in other assessment methods beyond I/O modeling. One such alternative approach includes the ex post econometric analysis of employment impacts.

The econometric approach is based on actual data on the changes in sectoral employment across various regions over a certain time period (e.g., Moretti 2010). It avoids many of the rigidities in $\mathrm{I} / \mathrm{O}$ modeling and indicates how particular sectors may be more benefited (or hurt) than others due to the presence of increases in the employment of one particular sector. Nevertheless, so far there have been few applications in the empirical context of mining employment. One exception is Fleming and Measham (2014), who employ this approach on Australian regions. They find evidence of significant indirect employment impacts for some local services (e.g., transport, rental, and accommodation services), but insignificant impacts in the tradable goods sectors (e.g., manufacturing, agriculture, etc.). Additional studies include Black et al. (2005) and Fleming and Measham (2015) (see further "Methodological approaches in previous empirical research" section).

The purpose of this paper is to apply a novel econometric approach to assess mining-induced job multipliers in the empirical context of northern Sweden. The econometric analysis relies on data on the number of employees in the non-mining sectors and in the mining sector, respectively. The regressions are made for two 5-year periods, 2003-2008 and 2008-2013, and we also highlight inter-county effects. The mining industry is important for Sweden, but especially for the two most northern counties, Norrbotten and Västerbotten, where the lion share of the Swedish mines are located. The empirical analyses focus on these two counties, and therefore neglect the remaining municipalities in the country. Due to the recent commodity boom, investments in new mines have been exceptionally high in these counties. Since historical unemployment rates have been high, the prospects of new mines, providing large-scale employment opportunities at relatively attractive wages, may often be welcomed with open arms by parts of the local population as well as by the local and regional authorities. Earlier studies of the job multiplier of mining in Sweden have however almost exclusively relied on the use of input-output models (e.g., Vasco Advisers 2014; Ejdemo and Söderholm 2011; Hansson et al. 2010; Sörensson 2003), thus potentially giving rise to misleading ex ante estimates of the employment impacts following new mining activity.

The reminder of the paper proceeds as follows. "Mining in Sweden and the recent mining boom" section provides a brief introduction to the recent mining boom from a Swedish perspective. In "Mining and regional employment: theory and empirical work" section, we discuss the employment impacts 
of mining addressing the nature of both direct and indirect development impacts. This section also gives an overview of the empirical research attempting to measure these impacts in various geographical contexts. "Methods and data" section introduces the empirical specifications and the data used in this paper, while the results are presented and discussed in "Empirical results" and "Discussion" sections, respectively. Finally, "Concluding remarks" section concludes the paper.

\section{Mining in Sweden and the recent mining boom}

In Europe, Sweden is a dominant mining country, especially in the iron ore market where the state-owned company LKAB supplies over $90 \%$ of total iron ore production in the European Union (Geological Survey of Sweden 2016). The importance of mining is also reflected in Swedish exports. The mining industry, including steel, represents about $10 \%$ of the country's gross exports and about $60 \%$ of the net exports (Vasco Advisers 2014). Figure 1 provides a historical perspective of mining's contribution to employment in Sweden and displays total production and the number of employees in the Swedish mining sector over the period 1950-2008. It displays that since the beginning of the $1980 \mathrm{~s}$, mine production in the country has increased substantially. Still, at the same time staff requirements have become significantly lower due to investments in productivity improvements.

As was noted above, mining plays - and have played - a particularly important role in the northern parts of Sweden. In 2016, there were 12 active mines in northern Sweden, six in the county of Norrbotten and six in the county of Västerbotten. ${ }^{3}$ Norrbotten accounts for over $83 \%$ of the export value of mining, and of the total exports from this county $64 \%$ are mineral products. The dominant part of this can be attributed to iron ore. Our focus on these two counties is also motivated by the fact that in 2013 these counties' share of total mining employment in Sweden amounted to 93\% (Statistics Sweden 2015).

Ejdemo et al. (2014) have calculated location quotient (LQ), i.e., a measure of regional specialization, ${ }^{4}$ for different industrial sectors in Norrbotten. The location quotients were calculated using data for the year 2012. This ratio illustrates the concentration of regional employment

\footnotetext{
${ }^{3}$ In the county of Norrbotten, the Kirunavaara, Gruvberget, Mertainen, Leveäniemi, and Malmberget mines extract iron ore while the Aitik mine extracts base metals and mainly copper. In the county of Västerbotten, the Björkdal, Kankberg, and Svartliden mines mainly extract gold while the Renström, Maurliden, and Kristineberg mines extract base metals (Geological Survey of Sweden 2016).

${ }^{4}$ Specifically, $L Q_{i} \equiv\left(e_{i} / e\right) /\left(E_{i} / E\right)$ where $e_{i}$ denotes employment in industry $i$ in the county, $e$ is the total employment in the county, $E_{i}$ is the employment in industry $i$ in the reference area (Sweden as a whole in our case), and $E$ is the total employment in the reference area.
}

in specific industries compared to the national average for that industry (Leigh 1970). If the ratio for a particular industry is equal to one (1), it means that the industry has the same share of total employment at the regional level compared to the national level. In Norrbotten, the extraction of minerals has a location quotient of 19 , thus indicating how far specialized the county has become in the mining sector in terms of employment. Specifically, this shows that the share of mining employment out of total employment is 19 times higher in Norrbotten compared to that of the country as a whole. Performing the same calculation for Västerbotten with data for 2012 yields a corresponding location quotient of 3.9. This shows that mining represents an important specialization also in Västerbotten, but regional employment is not nearly as concentrated to mining there as it is in the county of Norrbotten.

This implies in turn that the regional economies of northern Sweden, and that of Norrbotten in particular, will be sensitive to the price developments in the international commodity markets. As described earlier, the prices of mineral products have had a volatile development since the beginning of the new century. Figure 2 illustrates the development of iron ore prices over the period 2003 2016. Here, we clearly see the presence of both boom and bust in the iron ore market. Considering that the largest mines in Norrbotten produce iron ore, the mining industry in this county did very well during the booming years. Substantial mining investment took place, and the number of employees in the sector increased by over $30 \%$ between the years 2003 and 2013 (Statistics Sweden 2015).

Still, since mining is an industry that requires large capital investments and the number of direct jobs is relatively low, at least compared to historical times (see Fig. 1), the most significant employment opportunities have not necessarily emerged in the remote and sparsely populated regions where the mines are located. In the Swedish case, this has been noted by, for instance, Müller (2015).

\section{Mining and regional employment: theory and empirical work}

\section{The theoretical basis of the job multiplier}

An important point of departure for understanding the concept of the job multiplier is the staple theory, which describes the economic linkages that the mining industry has to the local economy. Watkins (1963) and Bertram (1967) relied on Innis (1956) and Mackintosh (1964) and developed the staple theory, and more specifically a 
Fig. 1 Production and number of employees in the Swedish mining industry, 1950-2008. Source: Geological Survey of Sweden (2011)

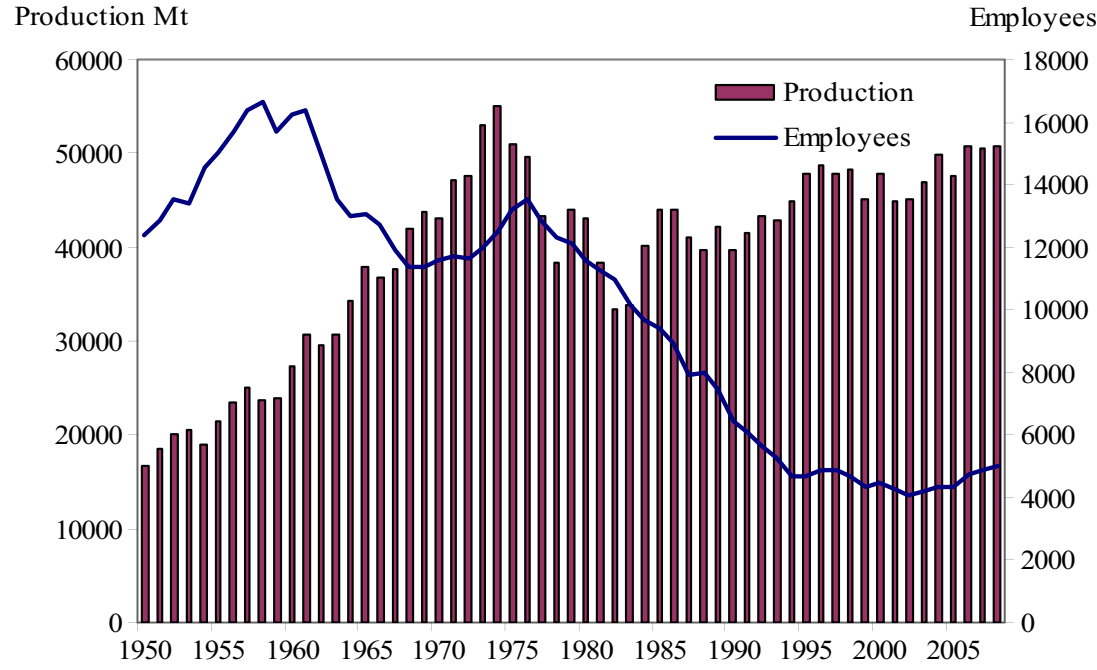

model that could be used to analyze the regional development impacts of natural resources that are extracted from the nature and then exported (Gunton 2003). This theory identifies that the mining industry gives rise to spillovers in the form of linkages to the rest of the economy. These linkages can in turn be divided into four different types:

- Forward linkages imply that the minerals from the mining industry can be used as a raw material in another local industry, i.e., downstream activities such as processing, refining, and fabricating the crude ores and concentrates. For instance, in Sweden, the mining industry supplies the steel industry with iron ore.

- Backward linkages refer to the local production of inputs to the mining industry, i.e., the supplies needed for an investment to be implemented, such as machinery and infrastructure (e.g., a new railway).

- Demand linkages refer to the incomes that employees at the mine and their households spend on goods and services in the local community or in the adjacent region.

- Fiscal linkages represent the enlargement of the public revenues when taxes from the mining industry accrue to the local government. This means that the local government has more money to spend and invest in the community.

It should be noted that the econometric approach outlined in section "Methods and data" does address the first three of these linkages. The fiscal linkage (at the local and regional levels) is, though, likely to be modest in the Swedish case
Fig. 2 Iron ore prices in the international market, 2003-2016 (CFR Tianjin port, 62\% FE). Source: IMF (2016)

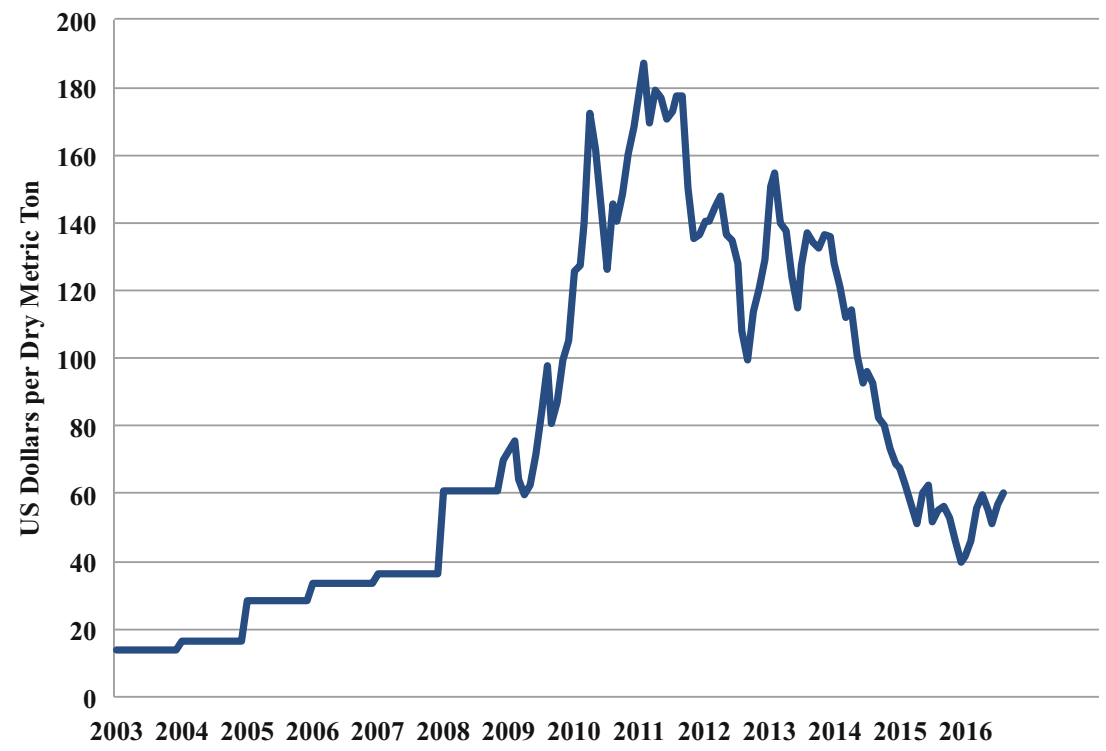


since the tax revenues from mining are not channeled back to the municipalities. However, the econometric approach does not permit us to distinguish between the different types of linkages.

The magnitudes of these linkages will depend on how well the local community can take advantage of the opportunities offered by the mining industry. The regional employment impacts of mining will depend on the specific circumstances related to each case, such as the size of the mine and the community, geographical location, and the presence of mining cluster activities (Archibald and Ritter 2001). It should however be noted that these linkages only address the increased induced demand for products and services in a region. Often there may also exist supply constraints offsetting these impacts. For instance, the increased demand for labor may also bid up wage levels, thus potentially diminishing the competitiveness of other private sectors and/or raise the cost of providing public services.

The indirect impacts of mining ventures are often expressed through so-called multipliers, which embody the effects of changes in demand for various goods and services (e.g., overall output) as well as inputs (e.g., labor) caused by the initial change in economic activity in mining. In this paper, we are primarily interested in the so-called job multiplier, thus showing how many jobs arise in other sectors of the economy as one new mining job sector is created.

Moretti (2010) makes a distinction between the tradable sector and the non-tradable sector. The former refers to the industry sector that trades goods, $x_{1}, x_{2}, x_{3}, \ldots x_{n}$, in the international market and where the prices of these products are set internationally. The non-tradable sector is the sector that is local and where prices of the goods, i.e., $z_{1}, z_{2}, z_{3}, \ldots z_{n}$, are set by local supply and demand conditions (e.g., housing brokers, health care, and education). Moretti (2010) also assumes that labor is perfectly mobile and can move between sectors in the local community; this assumption is likely to hold in the long run. The local labor supply curve is assumed to have an upward slope and the higher the geographical mobility is the higher is also the elasticity of labor supply.

Suppose now that there is an exogenous shock to regional economy in the sense that the demand for labor increases permanently in sector $x_{1}$. The direct effect of this shock is the increased employment in sector $x_{1}$. The indirect effect is what happens in terms of new jobs in the rest of the sectors, i.e., the traded goods' sector $x_{2}, x_{3}, \ldots x_{n}$ and the non-traded goods' sector $z_{1}, z_{2}, z_{3}, \ldots z_{n}$. As employment increases in sector $x_{1}$, incomes increase due to higher tax revenues, more workers, and higher wages. This means that the demand for non-traded goods $z_{1}, z_{2}$, $z_{3}, \ldots z_{n}$ increases, i.e., the number of work hours in restaurants, health care, education, and other similar jobs increases as well. These new jobs are divided between people that are moving into the region and people who already live there, and the exact nature of this distribution will depend on the degree of geographical mobility. The size of the resulting multiplier effect on the non-traded goods sectors will be influenced by three different factors:

- The type of jobs that are created in the tradable goods' sector. For instance, high-skilled jobs with higher wages will generally generate a larger multiplier and more jobs in the non-tradable sector. This is because the higher wages provide the workers with more money to spend on local services.

- There are opposing effects on wages and prices as the demand shock also increases the cost of labor and there is a decline in the supply of local services. The magnitude of this offsetting impact will in turn be influenced by the elasticity of labor supply, e.g., the crowding-out effect being smaller in the presence of an elastic labor supply.

- The technology, e.g., labor-intensive technology provides a higher multiplier, and the preferences for the nontradable goods locally.

The external shock to $x_{1}$ may also affect the other tradable sectors $x_{2}, x_{3}, \ldots x_{n}$, but whether this effect will be positive or negative is a priori unclear. Specifically, this will depend on four different factors:

- When the cost of labor increases locally because of the increased demand for labor in sector $x_{1}$ this will have negative impacts on companies in the other tradable goods sectors $x_{2}, x_{3}, \ldots x_{n}$.

- Unlike in the non-tradable sectors, the prices for the tradable goods are set in international markets and it is not possible for the producing companies to pass through increased costs to their consumers. In the long term, this can lead to businesses in the tradable sectors moving their production to places where labor is less costly.

- The increased output of $x_{1}$ may lead to an increasing demand for intermediate goods and services. This can affect the other companies in the tradable sector depending on how internationally dependent they are.

- Companies that are similar or have related activities tend to place their businesses close to each other (i.e., agglomeration effects); if this is important, it can have a positive effect on the tradable sectors.

Finally, in diversified regions, mining could also spur innovative activities among suppliers, in turn, giving rise to know-how that spill over to other sectors. Such dynamic effects can be difficult to assess empirically in detail. One may note, though, that labor productivity in modern economies is largely dependent on the use that is made of factor inputs (apart from capital expenditures as such) 
(Humphreys 2002). This should provide scope for innovative industries (e.g., ICT) to add to regional mining clusters since such spillover effects are likely to be most easily appropriated when activities are in reasonably close proximity to one another.

\section{Methodological approaches in previous empirical research}

In order to empirically estimate the local job multiplier, two commonly used methods are either I/O modeling or an econometric approach. As was noted in the introduction, the $\mathrm{I} / \mathrm{O}$ approach formalizes the backward and forward linkages between various sectors in a regional economy, and empirically, it has been applied to specific mining regions or ventures. For instance, Eggert (2001) notes that previous empirical studies of mining's impacts in Australia have generated an employment multiplier of 2. Important I/O studies on Australian regions include Ivanova and Rolfe (2011), Tonts (2010), and Rolfe et al. (2011), the last of these concluding that in Queensland, the indirect impacts from the mining industry have been distributed widely in the regional economy. Tonts (2010) points, though, to the presence of long-distance commuting in Western Australia leading to limited regional benefits.

In Sweden, a majority of the I/O modeling studies have relied on the use of the so-called rAps-model. This model comprises five different modules, which in combination represents a regional economy. The model is linked to a detailed regional proprietary database maintained by Statistics Sweden, and it operates through a demand-driven iterative process between the five modules. A schematic overview of the model is presented in Fig. 3. In the first module, population, a baseline population projection for a given year is calculated. This provides input data for the second module, labor market, where a preliminary estimate of the size of the labor force is calculated. Module 3, regional economy, calculates gross production, incomes and demand for labor. Initially, a preliminary estimate is calculated for the 49 sectors represented in the model. The fourth module considers the housing market with respect to the population projections from module 1 . The model then performs several iterations between modules 2 and 3 to balance the labor market against the regional economy, solving for the condition that the number of people in the labor force plus net commuting corresponds to the number of employed plus unemployed people. Finally, module 5, the municipal model, breaks down the results in further detail and calculates the municipal incomes and expenditures based on current taxes and government grants. The technical details of the rAps model are available in Statistics Sweden (2009).

In Sweden, the rAps-model has been employed by, for instance, Ejdemo (2013), Ejdemo and Söderholm (2011),
Hansson et al. (2010), Anderstig and Wigren (2009), and Sörensson (2003) and with a strong focus on iron ore projects in the county of Norrbotten. The job multipliers in these studies vary between 1.2 and 2.5 , meaning that one direct job in mining may generate between 0.2 to 1.5 additional jobs. The differences in results depend in part on the assumptions made about commuting behavior and the in-migration rate.

The use of I/O modeling has however been criticized for building on restrictive assumptions, which may bias the results presented in the above work (Fleming and Measham 2014). First, these models assume that factor supplies (including labor and capital) at the regional level are perfectly ownprice elastic (i.e., easily available) (Weber 2012). This means in turn that these analyses always generate positive job multipliers, and that there is no crowding-out effects from, for instance, higher wages, etc. Second, the I/O models will sometimes neglect the employment effects in the non-tradable goods sector and not the least potential gains such as agglomeration effects (Moretti 2010). Finally, these models are static, thus neglecting changes in technology, innovation as well as the often lengthy adjustments to the economic injections provided by mining ventures. For this latter reason, they also tend to be of limited use when depicting scenarios for the future (Kilkenny and Partridge 2009).

Given these limitations, there has also been an increased interest in other assessment methods, such as (a) computable general equilibrium (CGE) models and (b) ex post econometric modeling. The CGE models are extensively used for scenario analysis of the implementation of different economic policy measures (e.g., taxes), and they do also address the relative price changes following changes in the economy (e.g., Ye 2008; Törmä et al. 2015). ${ }^{5}$ CGE models typically depart from the national supply and use tables (the national accounts). These data are then regionalized by using criteria based on economic theory and the requirements of the national and regional accounts. Nevertheless, although CGE models typically contain fairly sophisticated representations of economic linkages across sectors, they are mostly designed for national and international settings; the assessment of the regional impacts of mining requires a narrower geographical scope.

Considering the limitations of both I/O and CGE modeling, scholars have increasingly employed ex post econometric models to measure the significance of employment impacts (Moretti 2010; Marchand 2012). Here, data on changes in sectoral employment across regions over a certain time period are collected, and in the econometric specification these data can be regressed on changes in, for instance, mining employment. A key output is the elasticity of employment

\footnotetext{
${ }^{5}$ It may be noted that often CGE modelers only present total effects, and not separate job multipliers. However, the latter can be easily be derived given access to information about the direct mining jobs.
} 
Fig. 3 Schematic overview of the Swedish I/O model rAps. Source: Statistics Sweden (2009)

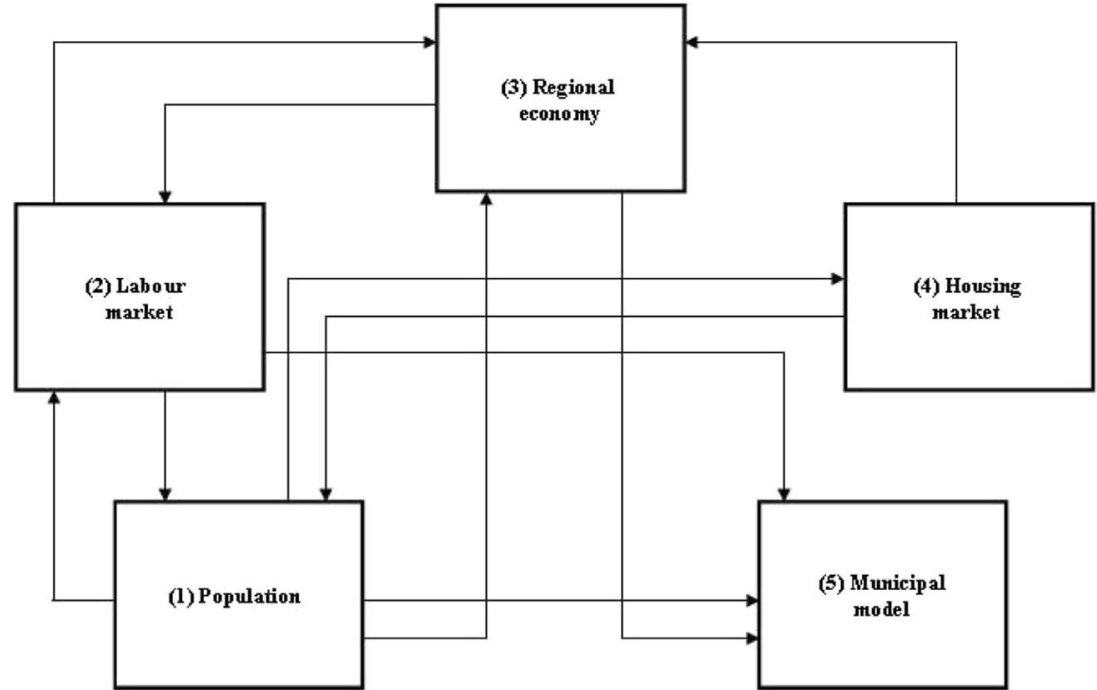

change in a particular sector with respect to changes in mining employment. Based on this information, the employment multiplier can be calculated. Previous studies in the empirical context of mining include Black et al. (2005) on the US coal industry, Fleming and Measham (2015) on the rise of the coal seam gas industry in Australia, and Fleming and Measham (2014) on the Australian mining regions.

However, using such econometric models to empirically estimate the employment effects of mining may also suffer from shortcomings. Van Dijk (2014) argues that the econometric approach can overestimate the job multiplier. He also questions making a distinction between tradable and nontradable goods sectors. In this paper, though, we follow the approach of Fleming and Measham (2014) and simply make a distinction between the mining sector on the one hand and a set of other sectors on the other (see further "Methods and data section").

\section{Methods and data}

The econometric model specification used in this paper builds on Moretti (2010), extended by Fleming and Measham (2014). The model estimates how many jobs that are created in the non-mining sectors when one new job in the mining sector is created, i.e., the local job multiplier. Thus, the following regression equation can be specified:

$\ln \left(\right.$ non-mining employment $\left.t_{t, i}\right)-\ln \left(\right.$ non-mining employment $\left.t_{t-1, i}\right)=$

$=\beta_{1}+\beta_{2}\left(\ln \left(\right.\right.$ mining employment $\left._{t, i}\right)-\ln \left(\right.$ mining employment $\left.\left._{t-1, i}\right)\right)+\beta_{3}$ year $+e_{i}$

In this equation, the dependent variable is the change in the $\log$ number of jobs in the non-mining sectors in time $t$ and municipality $i$. The independent variables are the change over time in the log number of jobs in the mining sector, while year is a dummy variable that equals one (1) in the first period and zero $(0)$ in the second period. The latter allows for timespecific effects, and thus essentially controls for potential structural variations across the two periods (see also Fleming and Measham 2014). Finally, $e_{i}$ is an error term.

The econometric specification is employed for a number of sectors in the municipalities of Norrbotten and Västerbotten and provides an estimate of the elasticity of employment change in a particular sector with respect to changes in mining employment. Based on these elasticities, we are able to calculate the local job multiplier for each of the sectors. This is achieved by multiplying their values by the ratio of sectoral employment to mining employment. For the sake of comparison with previous studies, it should also be noted that the methodology employed here yields a job multiplier for the non-mining sectors only, while previous studies which have estimated employment multiplier effects of mining in Sweden (e.g., Ejdemo and Söderholm 2011; Hansson et al. 2010; Sörensson 2003) typically calculate a multiplier for the total change in employment, thus including the direct employment in mining.

In order to estimate the local job multiplier, data over the number of employees in different sectors have been collected from Statistics Sweden. These data cover both full time and 
part time employment. The data cover all 29 municipalities in the counties of Norrbotten and Västerbotten, respectively, i.e., 15 in Västerbotten and 14 in Norrrbotten. Furthermore, we focus on employment changes across two separate time periods, 2003-2008 and 2008-2013. This panel data approach is an advantage over the $\mathrm{I} / \mathrm{O}$ approach, which needs to build on data for one representative year.

The full period (2003-2013) covers the entire mining boom period, including the year 2003 with initially low prices and the eventual bust in 2013. Moreover, one advantage of dividing the period into two sub-periods (apart from gaining more degrees of freedom), is that it permits us to account for structural changes over the total period (see above). The choice of 2008 as the dividing year is motivated by the advent of the global economic crisis in this year.

The data are divided into 17 different sectors, where one is the mining sector and the other 16 sectors are divided according to SNI 2007 (the most recent classification of economic sectors in Sweden). SNI2007 lists the following 16 sectors: agriculture, forestry and fishing, manufacturing and mining, energy and environment, construction, retail trade, transport, hotels and restaurants, information and communication, credit institutions and insurance companies, real estate, business services civil authorities and military, education, health and social care, personal and cultural services, and finally unknown. The manufacturing sector also includes mining, and for this reason, the mining employment has been subtracted from this category in order not to double count.

Table 1 shows the total number of employees by sector in Norrbotten and Västerbotten for the years 2003, 2008, and 2013. In the Appendix, we display these employment data separately for the counties of Norrbotten and Västerbotten (Tables 7 and 8). Table 1 shows that the total number of employees increased during the time period and in most of the individual sectors. The sector that most clearly decreases during is that of manufacturing between 2008 and 2013, in part a result of the financial crises starting in the autumn of 2008. There are also sectors that stand out in a positive way; these include the sector agriculture, forestry, and fishing for which the number of employees has more than doubled during the 10-year period 2003-2013. The latter conclusion is valid also for the mining sector, which increased its employment consistently during the same period. Specifically, between 2003 and 2013 , the number of mining employees increased by a total of $46 \%$.

The Swedish mining industry is limited to a few geographical locations ${ }^{6}$ and a relatively small share of the total

\footnotetext{
${ }^{6}$ For instance, in the Norrbotten county, mining currently takes place in the two municipalities Kiruna and Gällivare. In 2013, there were also one active mine in the municipality Pajala (this mine was only active between the years 2013 and 2014). However, some mining workers also commute from other municipalities, e.g., some are based in the municipality Lulea since this is where one of the largest companies (LKAB) has its headquarters.
}

population work in the mining industry. For our purposes, the above non-mining sectors have therefore been combined into four broader sectors. These are the industrial sector, private services, business sector, and government services. The industrial sector includes agriculture, forestry and fishing, manufacturing, energy and environment, and construction. Private services include retail trade, transport, and hotels and restaurants. The business sector entails information and communication, credit institutions and insurance companies, real estate, and business services. Finally, the government services sector includes civil authorities and military, education, health and social care, and personal and cultural services. The data over employment in these four aggregated sectors are presented in Table 2. Also here, there is evidence of important changes over the time period. All sectors increased in terms of employment, and this is particularly valid for the private services' sector.

\section{Empirical results}

In a first step, we consider the overall impact of the mining industry in northern Sweden by merging all 16 non-mining sectors into one aggregate. Three different specifications of this kind are analyzed. The first one includes all municipalities in Norrbotten and Västerbotten. The second model specification only includes municipalities in both Norrbotten and Västerbotten that host mine deposits. There are in total 10 municipalities with direct mining employment, and in this case we are interested to see if the results change when analyzing only the municipalities that are most directly affected by the mining. Finally, the third and last specification focuses on all municipalities in Norrbotten only. The largest mines are located in this county, and as indicate above, most of the mining employees reside in Norrbotten.

The estimation results from these three model specifications are presented in Table 3, and this displays differences across the two counties as well as across the mining and nonmining municipalities. Specifically, in the first specification embracing all municipalities, there is no statistically significant impact on the non-mining sector from employment increases in the mining sector. However, when addressing only the mining municipalities in the second model specification, we find a statistically significant elasticity on the aggregated non-mining sector, and a job multiplier of 0.85 . The elasticity of about 0.034 suggests that if the number of jobs in the mining industry increases by one (1) per cent the number of jobs in the other sectors increase by $3.4 \%$. Moreover, the estimated job multiplier indicates that if 10 direct jobs are created in the mining sector an additional 8.5 jobs are created in the rest of the municipality. Finally, in the model specification considering all municipalities in Norrbotten only, we get similar results as in the last case. The elasticity is statistically significant and 
Table 1 Employment by 17 sectors in the counties of Norrbotten and Västerbotten, 2003, 2008, and 2013

\begin{tabular}{llll}
\hline Economic sectors & 2003 & 2008 & 2013 \\
\hline Mining & 3845 & 4449 & 5622 \\
Agriculture, forestry and fishing & 4482 & 5908 & 9519 \\
Manufacturing & 30,699 & 30,967 & 26,615 \\
Energy and environment & 2821 & 3030 & 3425 \\
Construction & 13,642 & 17,940 & 19,973 \\
Retail trade & 20,655 & 22,742 & 22,893 \\
Transport & 11,989 & 11,998 & 12,347 \\
Hotels and restaurants & 5285 & 6443 & 7450 \\
Information and communication & 5768 & 6007 & 6170 \\
Credit institutions and insurance companies & 3001 & 2994 & 3001 \\
Real estate & 2763 & 3273 & 3453 \\
Business services & 14,245 & 19,875 & 22,188 \\
Civil authorities and military & 14,099 & 14,155 & 15,895 \\
Education & 29,920 & 28,365 & 28,852 \\
Health and social care & 45,344 & 46,781 & 49,023 \\
Personal and cultural services & 9155 & 9339 & 9939 \\
Unknown & 2905 & 2842 & 3301 \\
Total & 216,773 & 232,659 & 244,044 \\
\hline Source & & &
\end{tabular}

Source: Statistics Sweden (2015) the job multiplier increases to 0.99 (i.e., a total employment multiplier of close to 2).

In order to analyze which specific sectors in the region that are mostly heavily affected by increases in the direct employment in the mining industry, we also report results from model specifications in which we have divided the aggregated nonmining sectors into four separate sectors. Table 4 displays the results when all municipalities in Norrbotten and Västerbotten counties are included. The results show that the only positive and statistically significant impact can be found for the private services sector, which includes retail trade, transports and hotels and restaurants. In this case the estimated job multiplier is 0.49 , thus suggesting that 10 new jobs in the mining tend to induce an additional five jobs in the private services sector.

Tables 5 and 6 display the corresponding results when considering only municipalities where mining employment occurs (Table 5$)^{7}$ and when focusing only on the county of Norrbotten (Table 6). These results paint a very similar picture. In both cases, we primarily detect a positive and statistically significant impact on the private services sector, and here, the job multipliers range between 0.63 and 0.66 . Thus, municipalities with mining employment experience more employment increases in the private services sector in the

\footnotetext{
${ }^{7}$ In Norrbotten, there were four municipalities with mining employment over the relevant time period (i.e., Kiruna, Gällivare, Luleå, and Pajala), and in Västerbotten there were six municipalities (i.e., Norsjö, Malå, Storuman, Lycksele, Skellefteå, and Umeå).
}

presence of increases in mining sector employment. Municipalities in Norrbotten also appear to benefit more than the municipalities in Västerbotten. In addition, in the mining municipalities, we also find a positive and statistically significant impact (at the $10 \%$ level) on the industrial sector (Table 5). This sector includes, for instance, construction, energy and environment, and manufacturing. This strengthens the conclusion that job multipliers are stronger where mining is more present.

\section{Discussion}

The results presented above illustrate that there is a positive statistical relationship between increases in the number of employees in the mining sector and changes in the number of

Table 2 Employment by four aggregated sectors in the counties of Norrbotten and Västerbotten, 2003, 2008, and 2013

\begin{tabular}{llll}
\hline Economic sectors & 2003 & 2008 & 2013 \\
\hline Industrial sector & 51,644 & 57,845 & 59,532 \\
Private services & 37,929 & 41,183 & 53,350 \\
Business sector & 25,777 & 32,149 & 34,812 \\
Government services & 101,423 & 101,482 & 107,010 \\
Total & 216,773 & 232,659 & 244,044 \\
\hline
\end{tabular}

Source: Statistics Sweden (2015) 
Table 3 Job multiplier estimates: the mining sector versus one nonmining sector

\begin{tabular}{llll}
\hline Model specifications & $t$-statistics & Elasticity & Job multiplier \\
\hline All municipalities in both counties & 0.97 & 0.00648 & 0.352 \\
Mining municipalities in both counties & 2.48 & $0.03429^{\mathrm{a}}$ & 0.852 \\
All municipalities in Norrbotten only & 2.06 & $0.03158^{\mathrm{a}}$ & 0.989 \\
\hline
\end{tabular}

${ }^{\text {a }}$ Statistically significant at the $5 \%$ level employees in other sectors in northern Sweden. The private services sector is particularly affected, while the industrial sector also benefits in the case of mining municipalities. Overall, the job multipliers for non-mining sectors vary between 0.5 and 1.0 depending on the scope of the analysis. In comparison to other studies in which the mining job multiplier has been estimated in Sweden, the results here are similar. ${ }^{8}$ For instance, Hansson et al. (2010) estimated a job multiplier in the range $0.4-0.6$ for non-mining sectors, depending on which municipality in Norrbotten that was analyzed. Ejdemo and Söderholm (2011) estimated a multiplier of 1-1.5 for nonmining sectors in Pajala, while Ejdemo (2013) came up with a corresponding estimate of about 0.6. These previous studies all have in common that they are ex ante analyses, and they impose different assumptions about demographic changes in response to new mining activities. The scenario-based methodology employed in these studies is also the reason for why their results in terms of estimated job multipliers are presented as intervals, typically reflecting demographic outcomes that range from modest to expansive.

This ex post analysis suggests that the mining industry's impact on employment in non-mining sectors in northern Sweden tends to be underestimated in previous studies that have employed the rAps I/O model, with the exception of an expansive scenario in the study by Ejdemo and Söderholm (2011). This is somewhat surprising as the rAps I/O model neglects constraints in labor supply, and therefore does not consider crowding-out effects. This could lead to overestimated positive impacts. Another contributing reason could also be that the ex ante analyses cited above may not have accurately estimated the impact of mining development on demography, or failed to account for the emergence of new or expanding firms in mining's value chain. Nevertheless, overall our results are fairly consistent with those of other studies in spite of the methodological differences (e.g., ex post versus ex ante).

The result for the four different sectors illustrates that the sector private services is most affected by new jobs in the mining industry in northern Sweden. This result is not surprising given that private services include retail trade, transport, and hotels and restaurants. Thus, when more people are

\footnotetext{
${ }^{8}$ To avoid confusion regarding the comparison, we have adapted the notation of job multipliers from previous studies to reflect the effect on non-mining sectors, rather than the total change in employment as they are typically reported.
}

employed in the mining sector, they have more money to spend on local retail trade, something which increases the number of employees in this sector. Transports are also included in private services, and when the mining industry expands, demand for more transportation increases because more goods need to be moved to and from the mines. Hotels and restaurants are also included in private services. In the presence of more mining employment people will have more money to spend on restaurants. In addition, it also implies more business travels to the mine site in terms of consultants, prospective customers, and entrepreneurs.

The results do not indicate that there are statistically significant linkages between employment in mining and in the other three aggregates: industrial sector, business sector, and government services, except for in the mining municipalities where the industrial sector also benefitted from growth in mining. In the case of the industrial sector, there is an intuitive linkage since the construction industry is heavily involved in work related to the large mining investments that have taken place in northern Sweden during the last decade. The construction industry in the region added 6331 jobs between 2003 and 2013, but in this analysis, the employment effect may be offset by the loss of 4084 jobs during the same period in manufacturing, which is also included in the industry aggregate. Another possible explanation is that firms that participate in mining related activities may be located outside mining municipalities and even in other regions not considered here. This may in particular be true for highly specialized and knowledge intensive services such as technical and environmental consulting.

We do not find negative effects on any of the studied sectors. This may however in part be a consequence of the way in which the different sectors are aggregated. For instance, tourism is not included as a separate sector. It should be clear that tourism could be both hurt and

Table 4 Job multiplier estimates by sector: all municipalities in both counties

\begin{tabular}{llll}
\hline Sectors & $t$-statistics & Elasticity & Job multiplier \\
\hline Industrial sector & 0.87 & 0.01355 & 0.179 \\
Private services & 2.96 & $0.05155^{\mathrm{a}}$ & 0.492 \\
Business sector & 1.15 & 0.02709 & 0.189 \\
Government services & 0.93 & 0.02283 & 0.559 \\
\hline
\end{tabular}

${ }^{\text {a }}$ Statistically significant at the $5 \%$ level 
Table 5 Job multiplier estimates by sector: mining municipalities in both counties

\begin{tabular}{llll}
\hline Sectors & $t$-statistics & Elasticity & Job multiplier \\
\hline Industrial sector & 1.95 & $0.04871^{\mathrm{a}}$ & 0.426 \\
Private services & 4.55 & $0.09203^{\mathrm{b}}$ & 0.634 \\
Business sector & 1.81 & 0.03730 & 0.201 \\
Government services & -1.91 & -0.01408 & -0.238 \\
\hline
\end{tabular}

${ }^{\text {a }}$ Statistically significant at the $10 \%$ level

${ }^{\mathrm{b}}$ Statistically significant at the $5 \%$ level

benefitted from more intense mining activity. Specifically, sometimes mining is a tourist attraction in itself (e.g., the deep iron ore mine excursions offered in Kiruna), while it may also lead to less tourists if it interferes with the desire to experience pristine nature, etc. This relationship between employment in the tourism and mining sectors is an important topic for future research.

Our results also indicate that mining has a stronger indirect impact on employment in Norrbotten than in Västerbotten county. The estimated multiplier effect of mining on non-mining sector employment was 0.99 for Norrbotten compared to 0.85 when both counties were included in the specification. These results suggest that every 100 mining jobs in the Norrbotten county generates nearly 100 additional jobs in other sectors. There are several factors that may contribute to this result:

- The mining industry is overall a much more significant employer in Norrbotten than in Västerbotten. In 2012, Norrbotten accounted for approximately $82 \%$ of all mining employment in Northern Sweden;

- While mining is an important specialization in both counties, it represents a more distinct specialization in Norrbotten, as indicated by the location quotients we mentioned in "Mining in Sweden and the recent mining boom" section of this article; and

- Mining in Norrbotten county is dominated by iron ore ${ }^{9}$ which is a bulk commodity. In Västerbotten, the mining industry extracts base and precious metals which are not as bulky materials as iron ore. This suggests differences in infrastructure needs and logistics operations, and this may contribute to the stronger employment impact of mining in Norrbotten compared to Västerbotten.

These results correspond well with a recent ex post study by Tano et al. (2016), who used a propensity score matching estimator method to analyze the impact of the mining boom on labor incomes in mining towns in Norrbotten and Västerbotten. These authors found that the boom had caused

\footnotetext{
${ }^{9}$ Still, it should be noted that copper is also extracted at the Aitik mine in Gällivare municipality in Norrbotten.
}

Table 6 Job multiplier estimates by sector: all municipalities in Norrbotten only

\begin{tabular}{llll}
\hline Sectors & $t$-statistics & Elasticity & Job multiplier \\
\hline Industrial sector & 1.39 & 0.03376 & 0.202 \\
Private services & 2.25 & $0.06429^{\mathrm{a}}$ & 0.662 \\
Business sector & 1.54 & 0.04691 & 0.201 \\
Government services & -1.54 & -0.01684 & -0.242 \\
\hline
\end{tabular}

${ }^{\text {a }}$ Statistically significant at the $5 \%$ level

substantial growth in labor incomes in the case study areas over the time period 2004-2010, this compared to a "control group" of comparable residents in other geographical areas. Their results also indicate that the effect was much stronger in Norrbotten and the positive impact also involved more sectors of the economy, including those benefitted by increased household consumption, compared to Västerbotten county. Tano et al. (2016) argue that some possible explanations for the differences between the two counties could be that mining towns in Norrbotten are more dominated by mining, and that in comparison to Västerbotten, they are also more distant from the regional centers. Moreover, the result in Tano et al. (2016) that there are no significant income effects on the public sector supports our findings.

Overall, these results show that mining has a relatively strong positive impact on non-mining employment, but the impact appears to be limited mainly to the private services-aggregate. In the long run, technological progress will continue to reduce the amount of workers required to operate a mine, and this suggests over time diminishing spillover effects on the local economies. Communities and regions that depend on mining need to identify and implement strategies to face these challenges. These may comprise efforts aimed at achieving economic diversification, but losses of direct mining employment may also be offset to some extent by fostering a business climate which enables growth of local mining industry suppliers, ideally developing into a mineral cluster capable of internationalization as described by Wiberg (2009). However, firms that are engaged in specialized and knowledge intensive activities such as technical and environmental consulting may face challenges in attracting skilled labor to relatively remote mining communities.

\section{Concluding remarks}

The main purpose of this paper has been to assess the miningdeduced job multiplier for northern Sweden, using an ex post approach based on actual employment data. An important motivation for this research is to evaluate if previous ex ante estimates for the job multiplier assessed in this area have been sound. The results overall illustrate that there is a positive 
statistical relationship between increases in the number of employees in the mining sector and changes in the number of employees in other sectors in northern Sweden, as about one new job in the mining sector produces almost one new job in other sectors in the region. The estimates for the job multiplier from this ex post approach are further found to be similar to the estimates of job multipliers from previous input-output studies applied in this region, which are based on an ex ante approach. This result is reassuring since it implies that the earlier studies of the job multiplier of mining in Sweden, discussed in this paper, have not been providing misleading ex ante estimates of the employment impacts following new mining activity.

Regarding where the new jobs are created, in response to new jobs in the mining industry, we find that the private services sector is particularly affected. The private services sector includes employment in retail trade, restaurants and hotels and the increase in employees in this sector is not surprising given that these sectors are local, and if income from employment increases in a region, the private services sector often benefits the most from people with more money to spend. This result is also interesting as it implies that the results from the recent mining boom in northern Sweden did not suffer from fly-in/ fly-out effects, as a significant increase in the number of employees in Norrbotten is found. Further, it is found that in the mining municipalities, the industrial sector also benefitted from growth in mining. This is also intuitive since the construction industry is heavily involved in work related to the large mining investments that have taken place in northern Sweden during the last decade.

Another important conclusion to make is that there are relatively large inter-county differences between of the effects of mining in Norrbotten and Västerbotten. Our results indicate that mining has a stronger indirect impact on employment in Norrbotten than in Västerbotten county. The main explanation for this finding is given by important differences of the mining industries in the both counties. First, the mining industry in Norrbotten employs far more people compared to Västerbotten. Second, Norrbotten as a county is also to a larger extent specialized on mining. Third, iron ore dominates the mining industry in Norrbotten, and considering that it is a bulky product it increases infrastructure and logistics demands. It is thus possible that all of these differences contribute to the stronger employment impact of mining in Norrbotten compared to Västerbotten.

Finally, we would like to stress that in the long run, technological progress will likely continue to reduce the number employees required to operate a mine, and thus also reduce the spill-over effects of mining on the local communities. It is therefore important that communities and regions dependent on mining diversify their economies, and perhaps seek strategies to create so-called mineral clusters which are better equipped to face the challenges faced by mining communities with too much dependence on only extraction.

\section{Appendix}

Table 7 Employment by 17 sectors in Norrbotten county, 2003, 2008, and 2013

\begin{tabular}{llll}
\hline Economic sectors & 2003 & 2008 & 2013 \\
\hline Mining & 3118 & 3739 & 4642 \\
Agriculture, forestry and fishing & 1985 & 2831 & 4576 \\
Manufacturing & 13,187 & 13,199 & 11,782 \\
Energy and environment & 1417 & 1418 & 1623 \\
Construction & 7055 & 9817 & 10,875 \\
Retail trade & 9577 & 10,714 & 11,136 \\
Transport & 5913 & 5948 & 6273 \\
Hotels and restaurants & 2777 & 3473 & 3945 \\
Information and communication & 2922 & 2872 & 2822 \\
Credit institutions and insurance & 2540 & 1500 & 1509 \\
$\quad$ companies & 1297 & 1637 & 1712 \\
Real estate & 7265 & 10,401 & 11,385 \\
Business services & 8908 & 8612 & 9636 \\
Civil authorities and military & 13,883 & 12,739 & 12,238 \\
Education & 21,028 & 21,269 & 22,259 \\
Health and social care & 4510 & 4577 & 4792 \\
Personal and cultural services & 1645 & 1294 & 1543 \\
Unknown & 104,909 & 112,301 & 118,106 \\
Total & & & \\
\hline
\end{tabular}

Source: Statistics Sweden (2015)

Table 8 Employment by 17 sectors in Västerbotten county, 2003, 2008, and 2013

\begin{tabular}{llll}
\hline Economic sectors & 2003 & 2008 & 2013 \\
\hline Mining & 727 & 710 & 980 \\
Agriculture, forestry and fishing & 2497 & 3077 & 4943 \\
Manufacturing & 17,512 & 17,768 & 14,833 \\
Energy and environment & 1404 & 1612 & 1802 \\
Construction & 6587 & 8123 & 9098 \\
Retail trade & 11,078 & 12,028 & 11,757 \\
Transport & 6076 & 6050 & 6074 \\
Hotels and restaurants & 2508 & 2970 & 3505 \\
Information and communication & 2846 & 3135 & 3348 \\
Credit institutions and insurance & 1461 & 1494 & 1492 \\
$\quad$ companies & 1466 & 1636 & 1741 \\
Real estate & 6980 & 9474 & 10,803 \\
Business services & 5191 & 5543 & 6259 \\
Civil authorities and military & 16,037 & 15,626 & 16,614 \\
Education & 24,316 & 25,512 & 26,764 \\
Health and social care & 4645 & 4762 & 5147 \\
Personal and cultural services & 1260 & 1548 & 1758 \\
Unknown & 111,864 & 120,358 & 125,938 \\
Total & & & \\
\hline
\end{tabular}

Source: Statistics Sweden (2015) 
Open Access This article is distributed under the terms of the Creative Commons Attribution 4.0 International License (http:// creativecommons.org/licenses/by/4.0/), which permits unrestricted use, distribution, and reproduction in any medium, provided you give appropriate credit to the original author(s) and the source, provide a link to the Creative Commons license, and indicate if changes were made.

\section{References}

Anderstig C, Wigren A (2009) Regionalekonomiska effekter av nya gruvor i Pajala. WSP Analys \& Strategi, Stockholm

Archibald R, Ritter M (2001) Canada: from fly-in, fly-out to mining metropolis. In: McMahon G, Rémy F (eds) Large Mines and the community. Socioeconomic and environmental effects in Latin America, Canada and Spain. World Bank, Washington, DC

Bertram GW (1967) Economic growth in Canadian industry, 1870-1915: the staple model. In: Easterbrook WT, Watkins MH (eds) Approaches to Canadian history. McClelland and Stewart, Toronto, pp 74-98

Black D, McKinnish T, Sanders S (2005) The economic impact of the coal boom and bust. Econ J 115:449-476

Eggert RG (2001) Mining and economic sustainability: national economies and local communities, MMSD Report No. 19, World Business Council for Sustainable Development

Ejdemo T (2013) Mineral development and regional employment effects in northern Sweden: a scenario-based assessment. Miner Econ 25:55-63

Ejdemo, T., Söderholm, P., and Ylinenpää H (2014) Norrbottens roll $i$ samhällsekonomin. County Administrative Board of Norrbotten, Report 10/2014, Luleå, Sweden

Ejdemo T, Söderholm P (2011) Mining investment and regional development: a scenario-based assessment for Northern Sweden. Resour Policy 36:14-21

Fleming DA, Measham TG (2014) Local job multipliers of mining. Resour Policy 41:9-15

Fleming DA, Measham TG (2015) Local economic impacts of an unconventional energy boom: the coal seam gas industry in Australia. Aust J Agric Resour Econ 59(1):78-94

Geological Survey of Sweden (2011) Statistics of the Swedish mining industry 2010, periodic publications 2011:2. Geological Survey of Sweden, Uppsala, Sweden

Geological Survey of Sweden (2016) Statistics of the Swedish mining industry 2015, periodic publications 2016:1. Geological Survey of Sweden, Uppsala, Sweden

Gunton T (2003) Natural resources and regional development: an assessment of de-pendency and comparative advantage paradigms. Econ Geogr 79(1):67-94

Hansson G, Lundström A-K, Malmsten P, Anderstig C, Börjesson J, Annetorp Hörnsten C (2010) Malmfälten under förändring, Swedish Agency for Growth Policy Analysis, Report 2010:05, Östersund, Sweden

Humphreys D (2002) From economic to sustainable development: establishing a new framework for mineral extraction. Miner Energy 17(4):3-9

IMF (2016) IMF Primary Commodity Prices. Monthly Data. International Monetary Fund. Available at: http://www.imf.org/ external/np/res/commod/External Data.xls. 2016-11-14

Innis HA (1956) The fur trade in Canada, an introduction to Canadian economic history. University of Toronto Press, Toronto

Isard W (1951) Interregional and regional input-output analysis: a model of a space-economy. Rev Econ Stat 33(4):318-328

Ivanova G, Rolfe J (2011) Using input-output analysis to estimate the impact of a coal industry expansion on regional and local economies. Impact Assess Proj Apprais 29(4):277-288
Kilkenny M, Partridge M (2009) Export sectors and rural development. Agric Econ 91(4):910-929

Leigh R (1970) The use of location quotients in urban economic base studies. Land Econ 46(2):202-205

Leontief WW (1936) Quantitative input and output relations in the economic system of the United States. Rev Econ Stat 18(3):105-125

Mackintosh WA (1964) The economic background of dominionprovincial relations. McClelland and Stewart, Toronto

Marchand J (2012) Local labor market impacts of energy boom-bustboom in Western Canada. J Urban Econ 71(1):165-174

Moretti E (2010) Local multipliers. Am Econ Rev 100:1-7

Müller A (2015) Norrlandsparadoxen. Ordvisor förlag, Skellefteå, Sweden

O'Faircheallaigh C (2013) Community development agreements in the mining industry: an emerging global phenomenon. Commun Dev 44(2):222-238

Prno J (2013) An analysis of factors leading to the establishment of a social licence to operate in the mining industry. Resour Policy 38:577-590

Radetzki M (1982) Regional development benefits of mineral projects. Resour Policy 8(3):193-120

Rolfe J, Petkova V, Lockie S, Ivanova G (2007) Mining impacts and the development of the Moranbah township, research report no. 7, Centre for Environmental Management. Central Queensland University, Australia

Rolfe J, Gregg D, Ivanova G, Lawrence R, Rynne D (2011) The economic contribution of the resources sector by regional areas in Queensland. Econ Anal Policy 41:15-36

Statistics Sweden (2009) rAps - en beskrivning. Statistics Sweden, Örebro

Statistics Sweden (2015) Labour statistics based on administrative sources (RAMS), number of gainfully employed SNI 2007, 2003 2013. Statistics Sweden, Örebro

Söderholm P, Svahn N (2015) Mining, regional development and benefitsharing in developed countries. Resour Policy 45:78-91

Sörensson R (2003) Effektstudie av gruvetableringar i Lycksele och Storumans arbetsmarknadsregioner, CERUM Report 11:2003. Centre for Regional Science, Umeå University

Tano S, Pettersson Ö, Stjernström O (2016) Labour income effects of the recent "mining boom" in northern Sweden. Resour Policy 49:31-40

Tonts M (2010) Labour market dynamics in resource dependent regions: an examination of the Western Australian gold fields. Geogr Res 48(2):148-165

Törmä H, Kujala S, Kinnunen J (2015) The employment and population impacts of the boom and bust of Talvivaara mine in the context of severe environmental accident-A CGE evaluation. Resour Policy 46:127-138

Van Dijk JJ (2014) Local employment multipliers in U.S. Cities, University of Oxford, Department of Economics Discussion Paper Series, ISSN 1471-0498, United Kingdom

Vasco Advisers (2014) Mineralriket - tillväxtmotor för Norrbotten, Expandum, Progressum and Luleå Business \& Economic Development. Available at: http://mineralriket.se. 2016-11-14

Watkins MH (1963) A staple theory of economic growth. Can J Econ Polit Sci 29:141-158

Weber J (2012) The effects of a natural gas boom on employment and income in Colorado, Texas and Wyoming. Energy Econ 34:1580-1588

Wiberg U (2009) Förutsättningar för hållbar tillväxt $i$ gruv- och mineralsektorn, Report 0004. Swedish Agency for Economic and Regional Growth, Stockholm

Williams JP (2012) Global trends and tribulations in mining regulation. J Energy Nat Resour Law 30(4):391-422

World Bank (2010) Mining foundations, trusts and funds. A Sourcebook, Washington, DC

Ye, Q. (2008). Commodity Booms and Their Impacts on the Western Australian Economy: The Iron Ore Case, Resources Policy, Vol. 33, pp. 83-101 